\title{
The Socio-Economic Implications of Artisanal and Small-Scale Mining on Mining Communities in Northern Ghana
}

\author{
Chalisung Bernard Isung ${ }^{1}$, Yakubu Salifu${ }^{1}$, Thomas Azagsiba Agana ${ }^{2}$ \\ ${ }^{1}$ Social Sciences Department, Gambaga College of Education, Gambaga, Ghana \\ ${ }^{2}$ Simon Diedong Dombo University of Business and Intergrated Development Studies (SDD UBIDS), Wa, Ghana \\ Email: ibennard@gmail.com,yakubusalifu75@yahoo.com, aganathom@yahoo.com
}

How to cite this paper: Isung, C.B., Salifu, Y. and Agana, T.A. (2021) The SocioEconomic Implications of Artisanal and Small-Scale Mining on Mining Communities in Northern Ghana. Open Access Library Journal, 8: e7010.

https://doi.org/10.4236/oalib.1107010

Received: November 17, 2020

Accepted: March 13, 2021

Published: March 16, 2021

Copyright $\odot 2021$ by author(s) and Open Access Library Inc.

This work is licensed under the Creative Commons Attribution International License (CC BY 4.0).

http://creativecommons.org/licenses/by/4.0/

(c) (i) Open Access

\begin{abstract}
Small-Scale Mining (SSM) predates Large-Scale Mining (LSM) in Ghana but was relegated to the background in the 1980s following the Economic Reforms and Structural Adjustment Programmes which heavily liberalized the mining sector. Conversely, the small-scale mining sector continues to boom attracting a large chunk of the labour force in the mining sector. The small-scale mining sector has affected the livelihoods of several thousands of people especially those living in mining communities across the country. This study sought to ascertain the impact of small-scale mining on the livelihoods of people living in mining communities in the Northern Ghana. The study aimed at examining the socio-economic effects of artisanal and small-scale mining on the mining communities in northern Ghana. The approaches that were used to gather and analyse the data for the study included qualitative and quantitative research approaches. The study shows that the impact of small-scale Mining activities on livelihoods has been both positive and negative. It is recommended that small-scale mining firms should be required by law to introduce Alternative Livelihood Programmes or Interventions in the communities where they operate. Thus, communities can cope with the adverse effects of mining activities on their livelihoods.
\end{abstract}

\section{Subject Areas}

Development Studies

\section{Keywords}

Artisanal, Small-Scale Mining, Communities, Socio-Economic, Alternative Livelihood 


\section{Introduction}

The activities of Small-Scale Mining (SMM) is widespread in developing countries across the world and has affected the livelihoods of millions (Hentschel, Hruschka and Priester, 2002, [1] World Bank, 2013 [2] and Ontoyin and Agyemang, 2014 [3]). According to Hinton (2005) [4] small-scale mining is associated with environmental degradation, perilous work practices, pervasive poverty, HIV/AIDS, deplorable infrastructure, child labour, scant social services among others in communities where it is carried out. Despite this reality, small-scale mining provides an important source of livelihood, particularly in regions where economic alternatives are critically limited (Hinton, 2005) [4].

The International Labour Organization (ILO) (1999) [5] estimates that there are about 13 million people worldwide directly engaged in small-scale mining and an estimated 100 million people depend on it for their livelihood. However over the last two decades the sector has seen a dramatic escalation in its numbers which is attributable to a host of factors such as the rocketing gold prices, economic reforms, and increased demand for minerals among others (HilsonandPotter, 2005) [6] and Buxton, 2013) [7]. Small-scale miners extract a wide range and large quantity of minerals ranging from gold and precious stones to zinc, coal and bauxite (Buxton, 2013)) [7].

In Africa, the importance of mining to economic development cannot be overemphasized. The sector has played a key role in many African countries by its contribution to export revenues, Gross Domestic Product (GDP), employment and government tax revenues (Maponga, 2010) [8]. According to Maponga (2010) [8], the mining sector contributed $12 \%$ and $60 \%$ to GDP and merchandise exports respectively of Namibia in 2007; its share in Boswana 2006 was $40 \%$ of GDP and $88 \%$ of export revenues, in Zambia 2006, its contributed 6\% to GDP and $73 \%$ of export revenue. The activities of Small-Scale Mining played a key role in many African countries by its contribution to export revenues, Gross Domestic Product (GDP), employment and government tax revenues (Maponga, 2010) [8]. It is estimated that about four million people are directly involved in Small-scale mining in Africa and provides support to the livelihoods of about twenty million people (Hilson and Maponga, 2004) [9]. The mining small-scale mining sector in sub-Saharan Africa has seen a significant growth which is attributed to limited livelihood alternatives coupled with high levels of unemployment especially in rural areas where small-scale mining is pronounced (Lahiri-Dutt, 2004) [10].

Ghana has a long history of mining which predates the coming of the Europeans into the country (Akabzaa and Darimani, 2001) [11]. The mining industry, particularly small-scale mining, dates back to the 4th century when indigenous craftsmen made use of gold in diverse ways (Hayford et al., 2008) [12]. However, the exploration for gold took a higher dimension in the $15^{\text {th }}$ Century when the Europeans arrived, and commercial scale gold mining is believed to have begun in Ghana during the 19th century by the British (Tsikata, 1997 [13]; 
cited by Hayford et al., 2008: 1 [12]). It is said that the gold mining industry has been vibrant during the pre-independent era and is it $36 \%$ of total world gold output $\left(8,153,426\right.$ fine ounces) during the $15^{\text {th }}$ Century (Tsikata, 1997 [13], cited by Sarfo-Mensah and Awuah-Nyamekye, 2012 [14]).

In the post-independence period especially with the liberalization of the mineral industry in the 1980s there has been a massive influx of large scale transnational mining companies into the country (Hilson and Banchirigah, 2009) [15]. The government of Ghana in 2009 granted over 200 licence and leases to mining companies (Kuma and Yendaw, 2010) [16] as cited by Ontoyin and Agyemang, 2014) [3]. Aubynn (2012) [17] estimated that, there are over 1000 licensed small-scale mining companies in the mining industry of Ghana. Ghana therefore has a greater number of small-scale companies than Large scale ones.

The contribution of the mining sector to Ghana's economy is great. It is estimated that the mining sector contributes about $40 \%$ of Ghana's gross foreign exchange earnings with gold leading the chart. It also employs over 20,000 people for the large scale mining sector and over 500,000 people in the small-scale mining sector (Aubynn, 2012 [17], ISSER 2009 [18]; World Bank, 2008 [19]). Ghana is ranked the $8^{\text {th }}$ leading producer of gold in the world and contributed $43 \%$ to total merchandise export earnings (Ghana Chamber of Mines, 2013) [20]. The mining sector also contributed $27.04 \%$ (the highest) to the Ghana Revenue Authority in 2012.

Although the mining sector has experience substantial growth over the decades and is said to have been the major driver of Ghana's foreign exchange earnings, its impact on the mining communities has always been contentious. Most mining activities in Ghana are rural-based and affects to a large extent the traditional livelihoods of people living in these communities (Darimani 2010) [21]. This is because most rural folks depend on land and other natural resources for sustenance. In fact rural communities have been founded and shaped based upon their closeness and access to certain natural resources such as water bodies, forest, mountains and fertile lands of which land is particularly critical (Darimani, 2010) [21]. Both large scale and small scale mining activities therefore have several consequences on mining communities. However, small-scale mining is of particular significance to Upper East Region of Ghana which is also relatively endowed with several alluvial gold deposits and has become an attractive area for small-scale mining for many decades now (Hilson, 2006) [22]. It is worth noting however that most of the mining activities carried out in the region are on small-scale basis with illegal SSM dominating. Most small scale mining communities in the study area where mining is done are deprived and are heavily agrarian with high levels of poverty (Hilson, 2006) [22]. This study therefore looks at the effects of SSM on the livelihoods of the mining communities in the Talensi and Nabdam Districts in the Upper East Region of Ghana.

The contribution of the mining sector to the economy of Ghana is immense. According to Ayensu (1997) [23] and Aryee (2001) [24] Ghana earns a large 
chunk of its foreign exchange from gold exports and the sector also contributes significantly to the Gross Domestic Product (GDP) attraction of Foreign Direct Investment (FDI) to the country. In 2008 for instance, the sector contributed about $7 \%$ of Ghana's total corporate tax earnings, $41 \%$ of total export, $12 \%$ of government revenue collected by Internal Revenue Service and $5 \%$ of the Total GDP (Hayford et al., 2008) [12].

Whilst the mining sector is dominated by medium and large scale mining companies, of particular importance is the contribution of small scale mining to the economy and the mining communities especially. It estimated that about 4 million people are directly involved in directly SSM in Africa and the SSM sector is also estimated to provide support to the livelihoods of about twenty million people (Hilson and Maponga, 2004) [9]. In Ghana, although, no precise small scale employment figures exist, it is estimated that about 200,000 people are directly involved in the extraction of gold and diamond (Appiah, 1998 [25] as cited by Hilson, 2001 [26]), the greater majority are illegal.

Although the mining sector has contributed to the national economy as a whole, its impact on the mining communities is still in doubt. Most mining communities like Damang, Tarkwa, Prestea, Nangodi, Gbane etc are relatively deprived and are also exposed to several social, economic, and environmental hazards such as improper waste disposal, misuse of mining chemicals leading pollution of water bodies, loss of biodiversity, decline in air quality, land degradation as well loss of livelihoods (Awudi, 2002) [27]. Most of these rural communities where mining takes place are often left with no or limited livelihood choices due the effects of the activities on the natural environment (Anane, 2008) [28].

The northern Ghana (which includes Northern Region, Upper East Region, Upper West Region, North East Region and Savannah Region) is relatively endowed with mineral deposits especially alluvial gold and has been one of the most attractive destinations for Artisanal and Small-scale mining in Ghana (Hilson and Banchirigah, 2009) [15]. The region is largely rural and depends largely on subsistence agriculture for their livelihood (Ghana Statistical Service (GSS), 2012) [29]. Although Ghana has experienced a decline in the incidence of poverty for the last two decades Northern Ghana ranks high as of the most poverty endemic Region in Ghana. The incidence of poverty in the region is $70 \%$ which is more than $100 \%$ higher than the national average of $29 \%$ (GSS, 2007) [30]. Also according to the GSS (2007) [30] poverty is particularly evident in two sectors in Ghana of which agriculture is the most affected. This makes the Region more vulnerable to unsustainable use and exploitation of its scarce natural resources such as agricultural land, water bodies and the vegetation (Blench, 2006) [31].

Northern Ghana experienced an influx of migrants in the aftermath of the Structural Adjustment Programmes in the mid and late 1980s and 1990s into areas that are relatively endowed with alluvial gold deposits especially the 
Talensi and Nabdam Districts. Most of these migrants engaged in ASM which has left a devastating effect on the environment and hence the natural resource stock of the districts which has long defined their livelihoods (Hilson and Potter, 2005) [6].

Unlike the other mining communities in Ghana (e.g. Obuasi, Tarkwa, Prestea, Bogoso etc), there are no large scale mining companies in the area and all the mining activities are done at the small-scale level with illegal mining dominating (Hilson and Banchirigah, 2009) [15]. Due to the devastating effect mining has on the environment and for that matter the livelihoods of mining communities, most of the large scale mining companies such as Newmont Ghana, Anglogold Ashanti, all located in the southern part of Ghana, have introduced several alternative livelihood projects or schemes such as oil palm cultivation, cassava farming, snail rearing, poultry, grass-cutter rearing among others (Hilson and Banchirigah, 2009) [15]. In those communities to ameliorate the adverse effects of their activities on the livelihoods of the inhabitants of the mining communities. Conversely, in northern Ghana mining is of the small scale type and no such programmes and projects exist though the environment and for that matter the livelihoods of the inhabitants are being destroyed without remedy. In addition the mining activities are done illegally and these uncontrolled mining activities cause land degradation, pollute water bodies and the air. It also increases social vices in the mining communities leaving the inhabitants of these communities with limited livelihood choices and compelling some of them to engage in illegal mining activities for sustenance (Hilson and Potter 2005 [6]; Hilson and Banchirigah, 2009 [15]).

Much has been written on the effects of mining in Ghana (for example Tsikata 1997 [13]; Hilson 2001 [26]; Awudi 2002 [27]; Hilson, and Potter 2005 [6]; Akabzaa et al. 2007 [32]; Hayford et al., 2008 [12]; Botchie et al., 2008 [33]; Hilson and Banchirigah 2009 [15] etc.). Whilst some of these researchers concentrate on the socio-economic and environmental impacts of mining (Hilson and Potter 2005 [6]; Botchie et al. 2008 [33]; Awuah-Nyamekye and Sarfo-Mensah, 2012 [14]) other researchers also focused on the corporate social responsibilities of mining companies in the areas of alternative livelihood projects and provision of social amenities (Boon and Ababio 2009 [34]; Hilson and Banchirigah 2009 [15]; Yankson 2010) [35]. However most of these works are done in mining communities located in the southern part of Ghana (examples include Obuasi, Prestea, Tarkwa, Bogoso) and no particular attention has been paid to the effects of mining activities on livelihoods in Northern Ghana hence this study.

Given the above background, there is therefore inadequate in-depth assessment and understanding regarding the socio-economic impacts of small-scale mining on host communities in northern Ghana and how the communities are able to cope without alternative livelihood schemes.

\section{Methodology}

The mixed method (qualitative and quantitative) was adopted for this study. It 
provided tools for the researcher to study complex phenomena within their context using a variety of data sources. This ensured that the issue is not explored through one lens, but a variety of lenses which allowed for multiple facets of the phenomena to be revealed and understood. A total of 150 respondents (including officials of the institutions such as EPA, DAs, Forestry and Minerals Commission etc) from the three mining communities were selected using Miller and Brewer 2003 formula.

\section{Scope of the Study}

Within the context of this study, the focus is on Artisanal and Small-Scale gold mining because that is the predominant mining activity in Northern Ghana. The study centred on the effects of small-scale mining on livelihoods of the people in Northern Ghana.

Spatially, the study covered the mining communities in Upper East Region of Ghana. Particular interest was on the mining communities located in the districts and that included Nangodi, Duusi and Gbane. These communities were chosen because of their proximity to the mining sites and the intensity of mining in the same communities. The map of the study region is shown in Figure 1 below.

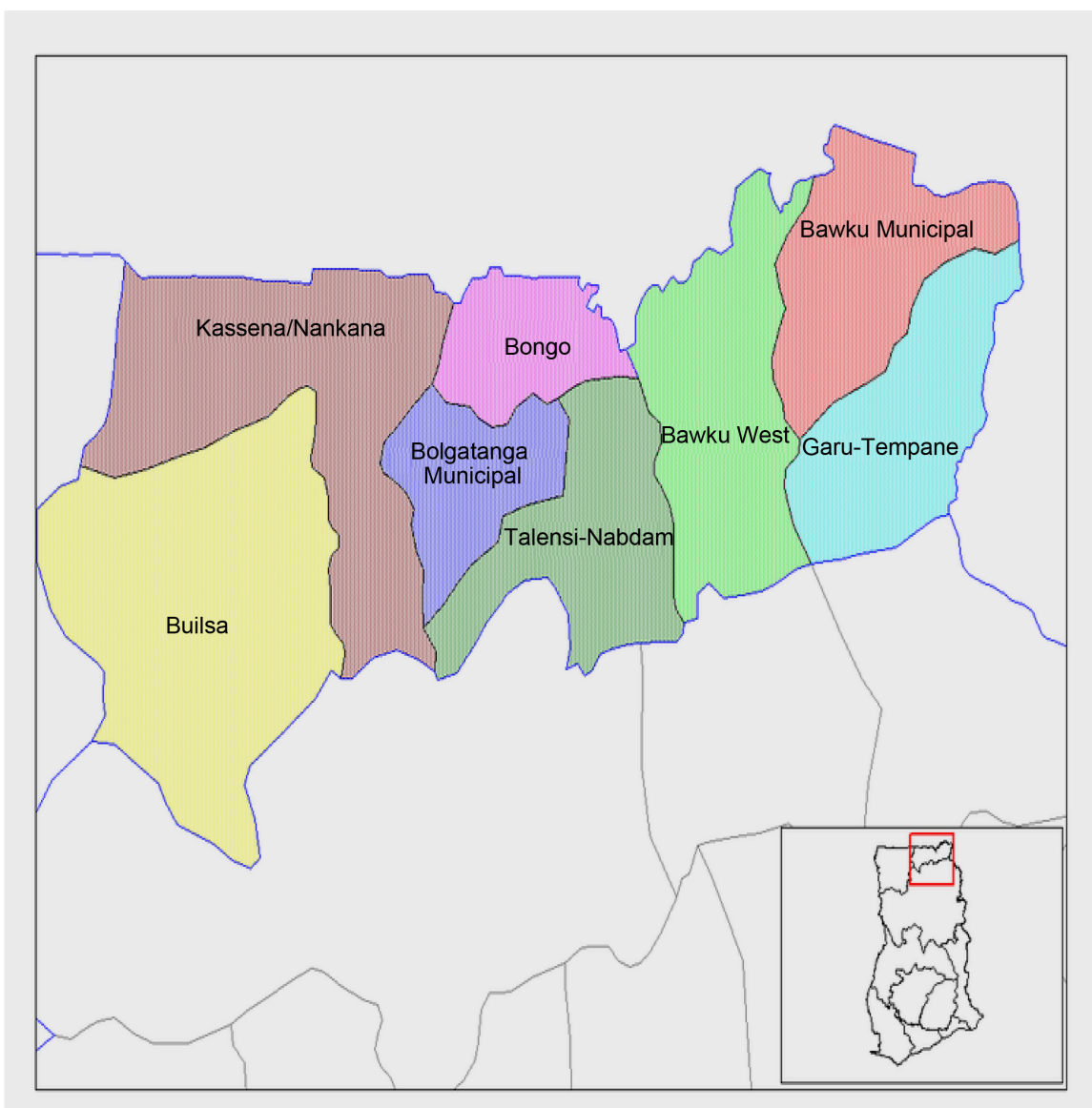

Figure 1. Map of the study region. Source: Bolgatanga Regional Profile, 2012. 


\section{Results and Discussions}

\subsection{Occupational Distribution of Respondents}

The respondents engaged in various economic activities ranging from farming to petty trading as shown in Figure 2 below.

Agriculture is the mainstay of the economies of the Talensi and Nabdam districts (NDA, 2014 [36] and TDA, 2013 [37]). From the survey, 66 constituting about $44 \%$ of the respondents were employed in the agricultural sector of the economy (subsistence farming). This is far below the district figure which puts it at over $80 \%$ (TDA, 2014 [38]). This implies that the economically active populations in the mining communities are moving from the agriculture sector to mining sector because the agricultural sector is becoming unviable comparative to mining (Hilson and Banchirigah, 2009) [15]. Small Scale Mining came next with 44 respondents constituting about $26.7 \%$. This shows that aside from Agriculture Artisanal gold mining employs the highest number of the economically active population in the study areas and is one of the main sources of livelihood to the people. About $13.3 \%$ were engaged in petty trading in the study areas. Majority of these petty traders were found at the mining sites providing services to the miners. This implies that Small Scale gold mining indirectly provides jobs for the petty traders who were mostly women. Only $9(6 \%)$ of the respondents were employed in the Public Sector which is attributable to the low level education prevalent in the area. About $7 \%$ of the respondents were unemployed and about $3 \%$ were employed in other sectors such as fishing, hunting, quarrying among others.

\subsection{Sex Distribution of Respondents}

Table 1 below shows the sex distribution of the respondents in the study areas.

The sex distribution of the respondents skewed towards males. Sixty-two percent (62\%) constituting 93 respondents were males whiles 57 representing 38\%

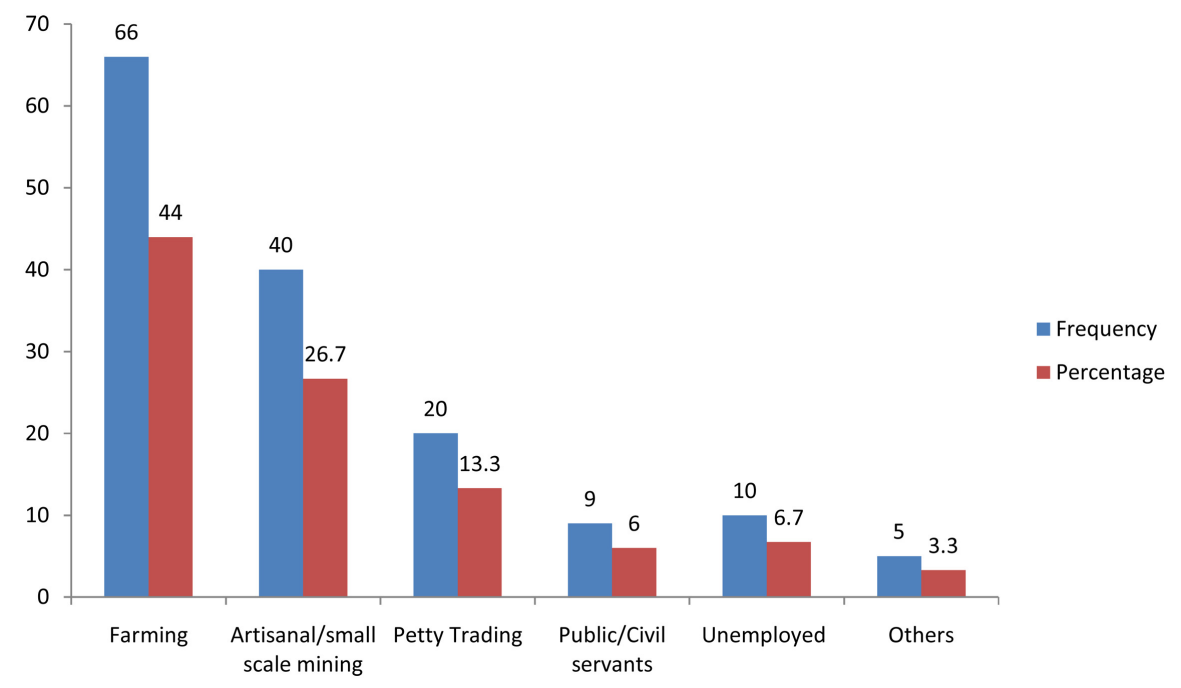

Figure 2. Occupational distribution of respondents. Source: Fieldwork 2016. 
of the respondents were females. This does not reflect the 2010 Housing and Population Census sex ratio of the districts (50.1\% females and $49.9 \%$ males) (GSS, 2012) [29]. This however shows that in the mining communities of the Talensi and Nabdam districts males dominate females. This is also attributable to fact that mining is traditionally a male oriented activity.

\subsection{Educational Status of Respondents}

The Table 2 below shows the levels of education attained or otherwise by the respondents in the study communities.

Education is livelihood asset and the higher the level of one's education the higher the chances of being able to access livelihood opportunities (DFID, 1999) [39]. From the survey as shown in Table 2, about 58\% of the respondents' attained basic education only, $19.3 \%$ had either secondary/vocational education. Only $2.7 \%$ attained tertiary education while $32 \%$ of the respondents never had any formal education. This statistics reveals that the educational level in the area is low and this could account for the reasons why many of people in the area found leverage Small Scale mining and farming since these occupations do not require any high educational qualifications in order to be employed in them. The mining activities in the areas could also account for the high school dropout rate in the area (Hilson, 2010) [40].

\subsection{Socio-Economic Effects of Small Scale Mining on Mining Communities}

\subsubsection{Employment}

Small Scale Mining sector is said to provide employment to several people in developing countries. The International Labour Organisation, (1999) [5] estimates

Table 1. Sex distribution of respondents. Source: Fieldwork 2016.

\begin{tabular}{ccc}
\hline Sex & Frequency & Percentage (\%) \\
\hline Males & 93 & 62.0 \\
Females & 57 & 38.0 \\
Total & 150 & 100.0 \\
\hline
\end{tabular}

Source: Fieldwork 2016.

Table 2. Educational level of respondents.

\begin{tabular}{ccc}
\hline Level of Education & Frequency & Percentage (\%) \\
\hline Tertiary & 4 & 2.7 \\
SHS/Technical/Vocational & 29 & 19.3 \\
JHS & 32 & 21.3 \\
Primary & 37 & 24.7 \\
No Formal Education & 48 & 32.0 \\
Total & $\mathbf{1 5 0}$ & 100.0 \\
\hline
\end{tabular}

Source: Fieldwork 2016. 
that about one hundred million people including dependent family members and participants in downstream industries depend upon the sector for their livelihood. In Ghana it has been estimated that the artisanal and small scale mining sector employs up to two hundred thousand people directly and about one million people if dependents are included (Hilson, 2002 [41], Hilson and Potter, 2005 [6]). The issue of the sector's ability to provide employment is attributed to its labour-intensive nature, low educational requirement and comparatively low cost of investment (Hilson, 2002) [41].

Over $80 \%$ of the respondents interviewed said SSM has directly and indirectly provided jobs and job opportunities to many community members who were once unemployed. The two major sources of livelihood in the study areas are farming and mining. It was evident from the interviews conducted that artisanal and small scale is the single most important source of employment to the youth especially, in the study areas. Some of the youth who could get any meaningful employment in the formal sector of the economy due to lack of skills or low level of education have been gainfully employed in the mining sector and this some of the respondents claim has also minimized the exodus of the youth to the southern part of the country in search of non-existent jobs. From the focus group discussions and the household interviews many of the people asserted that mining has come to salvage them from seasonal unemployment which is often associated with agricultural activities in the area. The study areas have two seasons, the rainy season and a prolonged dry season and because of this most farmers who become redundant during the dry season now engage in mining to make a living. The respondents also claim the land has lost its fertility because of continuous cropping and land degradation making farming an unviable business and hence artisanal mining serves as an alternative source of livelihood to them.

However most of the respondents were quick to add that the sector favours the non-indigenes than the indigenes in terms of employment because the non-indigene have huge capital and are always able to acquire large concessions for their mining activities and this they say coerces them into galamsey (illegal mining). The indigenes are referred to people from the mining communities whereas the non-indigenes are people who have moved from other communities and countries to mine in the communities.

Although the respondents could not mention the exact figures of non-indigenes involved in the mining activities they said they were in the majority constituting about $80 \%$.

\subsubsection{Agriculture}

Agriculture is described by the district assemblies as been the economic backbone of the study areas. And as the survey revealed majority of the respondents, $66 \%$ depend on agriculture for their livelihood. However agriculture is the single most affected economic activity by the mining activities and this is because mining and agriculture compete for the same scarce resources especially land and labour hence often generating an inevitable conflict. A key informant said 
the mining activities of Shaanxi Company alone have displaced over 500 farmers in the area rendering them jobless without any commensurate compensation. From the interviews conducted, respondents were a bit divided regarding the impact of artisanal mining on agriculture. The farmers who depended solely on agriculture for their livelihood argued that the effect of mining activities on agriculture was largely negative this is corroborated by Hilson and Banchirigah, (2009) [15]. The farmers cited land degradation, seizure of farmlands for mining companies, water pollution, siltation of rivers and the destruction of economic trees as reasons for their assertion. This they say affects both crop and livestock farming in the area and for that matter their livelihoods negatively. However farmers who doubled as miners saw mining to be complementary to agriculture. They said through mining they are able raise capital (money) to buy farm inputs such as fertilizers, pay casual workers and buy other farm implements. They also claimed during the dry season when farming activities are no more they depend on artisanal mining to cater for their needs.

It is worth noting however that the respondents who were basically farmers or depended solely on farming for their livelihood were more than the farmers who also did mining (about $10 \%$ of the farmers' population in the study). It is therefore appropriate to say that the effect of Small Scale Mining on agriculture has been largely negative.

\subsubsection{Education}

Education is a key to the socioeconomic development of every people and for this reason the study sought to unravel the effect of artisanal and small scale mining on this all important socioeconomic indicator. Through focused group discussions in the three communities Duusi, Gbane and Nangodi, respondents were somewhat unanimous in describing the effect of mining on the education of their wards. They said the mining activities have made many children of school-going age to drop-out of school. The officers of District Assemblies in the study also alluded that the high rate of school drop-out in area to the mining boom in the area though the trend was gradually changing. In my rounds during the field survey I saw a lot of minors who were supposed to be at school at mining sites and camps mining (Figure 3).

Some of the respondents claimed they could not finance the education of their wards because of poverty and this has caused the children to drop-out of school.

Some of the minors interviewed in the mining camps claimed they did not have any parental support and hence have to mine in order to make money to pay their school fees although this affects their studies adversely.

One of the respondents who is now in Senior High School had this to say;

"I started this mining when I completed my Basic Education Certification Education without any support to enter the Senior High School. So I decided to go into mining in order to finance my education. Some of my mates who could not pay their fees went the south to work in order to make money so as to pay their fees also". 


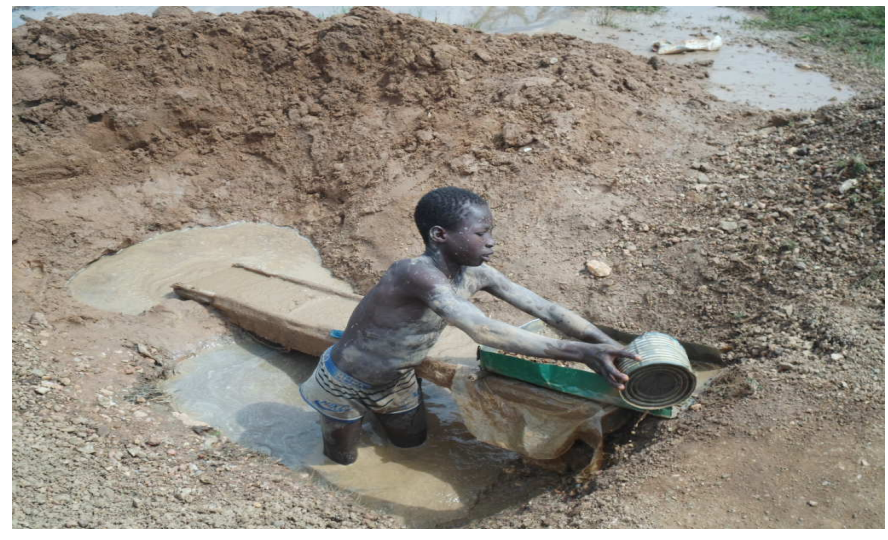

Figure 3. A Minor (13-years old) engaged in illegal mining operations at the Nangodi. Source: Fieldwork, 2016.

Conversely, some of the respondents interviewed said they use part of the incomes they generate through the mining activities to send their wards to school. One of the miners at Gbane who is part owner of a mining group called Unique Mining Group said he single-handedly financed the education of his siblings through the income he generates from mining and that one of them who completed his tertiary education at the Polytechnic is back to support him as an Accountant of the mining group.

In terms of constructing educational infrastructure in the mining communities ASM has not helped according to the head teacher of Nangodi D/A Primary School in anyway. In my interaction with one of the mining groups in "Obuasi" at Gbane he said they have always paid their due to chief and the district assembly and they expected them to use such royalties and revenue to put up schools in the area.

In general, mining activities in the area have not significantly contributed positively to child education in the area. The situation has caused some wellmeaning NGOs especially Afrikids to intervene in order to curb the negative impact of mining on education in the Talensi and Nabdam districts.

\subsubsection{Migration}

Migration is influenced by several factors but studies have shown that one pertinent pull factor of people into the study area has been Small Scale especially in mid 1990s (Hilson, 2001 [26]; Hilson and Banchirigah, 2009 [15]). Migration has an impact on the socioeconomic development of communities and this study sought to unravel the effect of migration on the mining communities in the Talensi and Nabdam districts. Most of the respondents said there had been an influx of people from other parts of Ghana, Burkina Faso, USA and China to the area.

Although they could not give exact figures they said the mining sector in the area has been dominated by non-indigenes. They approximated their number to be about $80 \%$ of the total mining population in the areas. Most of the non-indigene miners dwell in the camps according to the respondents and do 
nothing to develop the area. An observation of the Camps was indeed an eye-saw as presented in Figure 4. Although the indigenes could not deny the fact that the presence of the non-indigenes have opened up the local economy they however were of the view that the benefits derived from it is negligible. According to the indigenes the gains made from their resources are sent back to their hometowns to invest and build nice houses.

The respondents during a focus group discussion said the migrants are able to acquire larger concessions because they have money and are better equipped technically to prospect and to discover areas with large mineral deposits.

The respondents (indigenes) were afraid they may lose everything eventually to foreigners citing Shaanxi Mining Company limited as an example in the Gbane mining community.

According to a key informant at Gbane, out-migration which used to be pronounced in the area has however seen a massive decline since the youth now find leverage in the mining sector rather than travel down south in search of non-existent jobs.

\subsubsection{Health}

Mining is often associated with adverse health implications (Hilson and Potter, 2005) [6] on both miners and people living in and within mining communities. Although the District Assemblies have drilled boreholes for the communities, a key informant said both surface and underground waters have been contaminated posing serious health threats to the inhabitants. Through the Focus Group Discussions across the three communities most of the respondents said mining has actually made them to contract ailments such as Malaria, Tuberculosis (TB) and other Respiratory Diseases, Skin Diseases among others due to their exposure to dust and toxic chemicals which was corroborated by the disease chart of the Ghana Health Services of both districts. Miners use dangerous chemicals like cyanide and mercury without appropriate precautions and protective gears. It

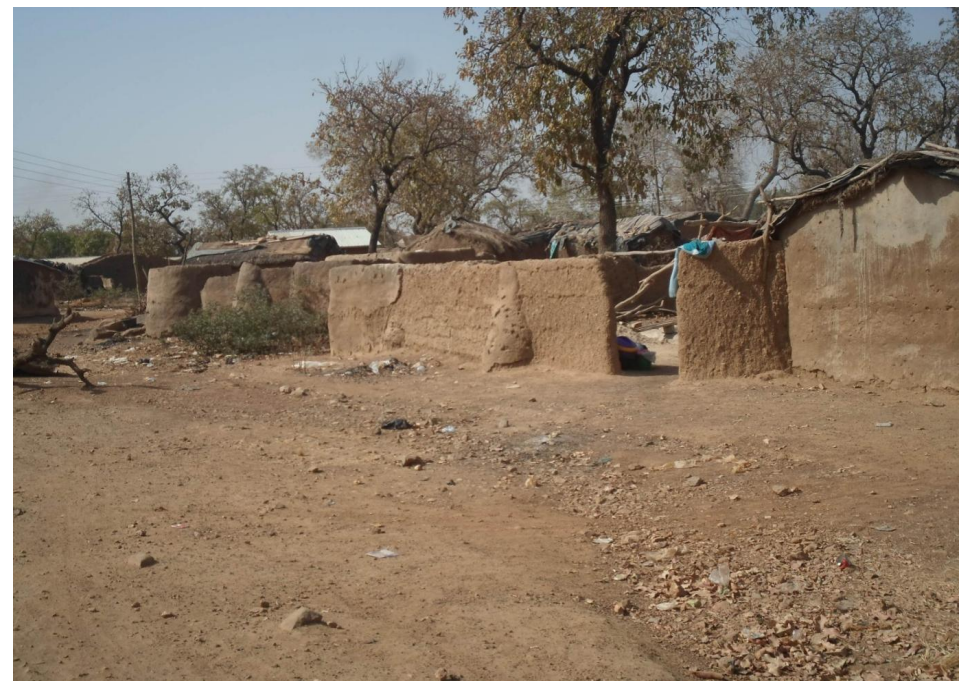

Figure 4. A typical mining settlement at gbane. Source: Filedwork, 2016. 
was observed that minors were exposed to mercury at Nangodi who claimed they were using it to extract the gold. Also some of the respondents said the use of the chemicals have also polluted the water bodies in the areas hence posing a health threat to the inhabitants. Another health threat was accidents related to mining. Some of the respondents said people have fallen into pits and either died or injured, others have also been buried when pits collapsed while others died underground by been choked by smoke from pumping machines.

The mining communities at Gbane did not have any health facility which the respondents believe is detrimental to their health because most of them at the mining sites result to self-medication.

Small scale mining has therefore adversely impacted the health status of the people and the communities at large.

\subsubsection{Poverty Alleviation}

Poverty is endemic in the area but with emergence of mining in the communities the incidence of poverty has relatively declined over the years. Although there are no official figures to determine the poverty levels of the people in the district, about $63 \%$ of the respondents thought mining have had a positive impact on poverty whiles the other $37 \%$ thought otherwise as shown in Figure 5 below. Majority of the respondents claimed small scale mining has provided employment for many people in the area and hence enhancing their livelihoods. The overall effect of Small Scale mining on the poverty situation of the communities has been largely positive. This is corroborated by a wide range of literature that asserts that the SSM sector is poverty-driven sector and has a potential of alleviating people from poverty (Hilson and Banchirigah, 2009) [15].

\subsubsection{The Local Economy}

The local economy of the study area is predominantly agrarian (NDA, 2013) [42]. According to Bloch and Owusu (2012) [43], the existence of both forward and backward linkages in the gold mining sector has caused a lot of businesses to spring up. Most of the respondents in the study area attested to this fact that the

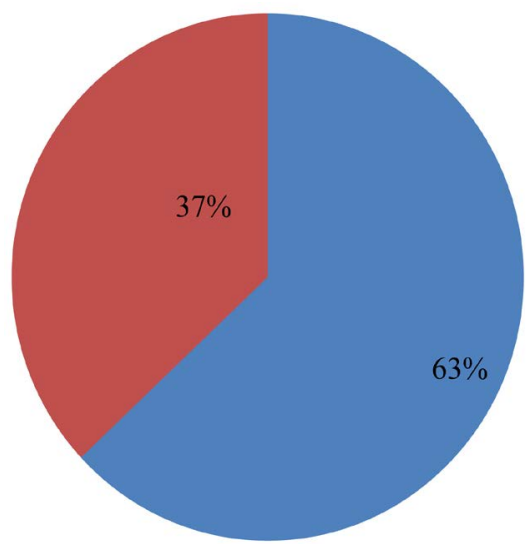

Figure 5. The effects of small scale mining on poverty alleviation. 
discovery and mining of gold in the area has opened up the place in terms of business opportunities. Many subsidiary businesses like petty trading, selling of alcoholic beverages, selling of mining inputs, food vending among others have sprung up and are doing well in these mining communities.

A key informant at the Gbane mining community said the community was without any commercial activity until the emergence of mining in the area. He said they did not have a market but now they have and do not need to travel long distances to buy certain basic items although the cost of living around the mining areas is relatively higher as compared to her areas.

\section{Conclusion}

The impact of artisanal and small scale on the social and economic lives of people living in mining communities could be improved if appropriate legislative and instruments are enacted to streamline their activities. Although several laws are already in place they could be best described as ad hoc without any meaningful impact on host communities.

\section{Recommendations}

Artisanal and small scale mining firms should be required by law to introduce Alternative Livelihood Programmes in the communities where they operate. This will compensate the people who either lose their sources of livelihoods to artisanal mining activities or whose livelihoods adversely impacted by their mining activities.

The Environmental Protection Agency should be equipped with the requisite staff and logistics to enhance their activities such as providing education on the environmental hazards of mining to miners in mining sites and communities and to enforce the laws governing the operations of the miners.

\section{Conflicts of Interest}

The authors declare no conflicts of interest regarding the publication of this paper.

\section{References}

[1] Hentschel, T., Hruschka, F. and Priester, M. (2002) Artisanal and Small-Scale Mining Challenges and Opportunities. International Institute of Economic and Development and World Business Council for Sustainable Development, Russell Press Ltd., Nottingham.

[2] World Bank (2013) Artisanal and Small-Scale Mining: Brief. The World Bank Group. http://www.worldbank.org/en/topic/extractiveindustries/brief/artisanal-and-small-s cale-mining

[3] Ontoyin, J. and Agyemang, I. (2014) Environmental and Rural Livelihoods Implications of Small Scale Gold Mining in Talensi-Nabdam District in Northern Ghana. Journal of Geography and Regional Planning, 7, 150-159. 
https://doi.org/10.5897/JGRP2014.0447

[4] Hinton, J. (2005) Communities and Small-Scale Mining: An Integrated Review for Development Planning. The World Bank, Washington DC, Human Well-Being, International Association for Impact Assessment, Fargo.

[5] International Labour Organisation (ILO) (1999) Social and Labour Issues in SmallScale Mines. Report for Discussion at the Tripartite Meeting on Social and Labour Issues in Small-Scale Mines, International Labour Organization, Sectoral Activities Programme, International Labour Office, Geneva.

[6] Hilson, G. and Potter, C. (2005) Structural Adjustment and Subsistence Industry: Artisanal Gold Mining in Ghana. Development and Change, 36, 103-131. https://doi.org/10.1111/j.0012-155X.2005.00404.X

[7] Buxton, A. (2013) Responding to the Challenge of Artisanal and Small-Scale Mining: How Can Knowledge Networks Help? International Institute for Environment and Development, London.

[8] Maponga, O. (2010). Transforming Artisanal and Small-Scale Mining for the Sustainable Livelihoods of Communities: Lessons and Options. In G. Hilson (Ed.), Enclaves of Wealth and Hinterlands of Discontent: Foreign Mining Companies in Africa's Development. Third World Network Africa 2010.

[9] Hilson, G. and Maponga, O. (2004) How Has a Shortage of Census and Geological Information Impeded the Regularization of Artisanal and Small-Scale Mining? Natural Resources Forum, 28, 22-33. https://doi.org/10.1111/j.0165-0203.2004.00069.x

[10] Lahiri-Dutt, K. (2004) Informality in Mineral Resource Management in Asia: Raising Questions Relating to Community Economies and Sustainable Development. Natural Resources Forum, 28, 123-132. https://doi.org/10.1111/j.1477-8947.2004.00079.x

[11] Akabzaa, T. and Darimani, A. (2001) Impact of Mining Sector Investment in Ghana: A Study of the Tarkwa Mining Region. A Draft Report, SAPRI.

[12] Hayford, E.K., et al. (2008) Impact of Mining on Soil and Some Staple Foods Collected from Selected Mining Communities in and around Tarkwa-Prestea Area. West African Journal of Applied Ecology, 14, 1-12. https://doi.org/10.4314/wajae.v14i1.44708

[13] Tsikata, F. (1997) The Vicissitudes of Mineral Policy in Ghana. Resources Policy, 23, 9-14. https://doi.org/10.1016/S0301-4207(97)00006-8

[14] Awuah-Nyamekye, S. and Sarfo-Mensah, P. (2012) Mining or Our Heritage? Indigenous Local People's Views on Industrial Waste of Mines in Ghana. In: Show, K.-Y., Ed., Industrial Waste, INTECH, London, 151-172. https://doi.org/10.5772/35740

[15] Hilson, G. and Banchirigah, S.M. (2009) Are Alternative Livelihood Projects Alleviating Poverty in Mining Communities? Experiences from Ghana. Journal of Development Studies, 45, 172-196. https://doi.org/10.1080/00220380802553057

[16] Kuma, J.S. and Yendaw, J.A. (2010) The Need to Regularise Activities of Illegal Small-Scale Mining in Ghana: A Focus on the Tarkwa-Dunkwa Highway. International Journal of Geosciences, 1, 113-120. https://doi.org/10.4236/ijg.2010.13015

[17] Aubynn, A.K. (1998) Mining Disputes in Ghana. Woeli Publications, Accra.

[18] ISSER (2009) The State of the Ghanaian Economy in 2008. ISSER, Accra.

[19] World Bank (2008) Ghana 2007 External Review of Public Finance Management. Report No. 40676-GH, World Bank, Washington DC. 
[20] Ghana Chamber of Mines (2013) Performance of the Mining Industry in 2012. Accra.

[21] Darimani, A. (2010) Mining Boom and Enclave Economy: Development Impact and Challenges in Mining Areas in Africa. In: Hilson, G., Ed., Enclaves of Wealth and Hinterlands of Discontent. Foreign Mining Companies in Africa's Development, Third World Network-Africa, Accra.

[22] Hilson, G. (2006) Challenges with Eradicating Child Labour in the Artisanal Mining Sector: A Case Study of the Talensi-Nabdam District.

[23] Ayensu, E.S. (1997) Ashanti Gold: The African Legacy of the World's Most Precious Metal. Marshall Editions Development Ltd., London, 27-32. https://doi.org/10.1023/A:1018583317587

[24] Aryee, B.N.A. (2003) Small-Scale Mining in Ghana as a Sustainable Development Activity: Its Development and a Review of the Contemporary Issues and Challenges. In: G. Hilson, Ed., The Socioeconomic Impacts of Artisanal and Small-Scale Mining in Developing Countries, A.A. Balkema, Rotterdam, 379-418.

[25] Appiah, H. (1998) Organization of Small-Scale Mining Activities in Ghana. Journal of the South African Institute of Mining and Metallurgy, 98, 307-310.

[26] Hilson, G. (2001) A Contextual Review of the Ghanaian Small-Scale Mining Industry. International Institute of Environment and Development, London.

[27] Awudi, G.B.K. (2002) The Role of Foreign Direct Investment (FDI) in the Mining Sector of Ghana and the Environment. The Conference on Foreign Direct Investment and the Environment, Paris, 7-8 February 2002.

[28] Anane, M. (2008) Farmers Resist Newmont Operations in Ajenua Bepo Forest.

[29] Ghana Statistical Service (2012) 2010 Population and Housing Census: Summary Report of Final Results. Ghana Statistical Service, May, 2012.

[30] Ghana Statistical Service (2007) Pattern and Trends of Poverty in Ghana, 1991-2006. Ghana Statistical Service, April 2007.

[31] Blench, R. (2006) Background Conditions in Upper East Region, Northern Ghana. Working Paper IFAD.

[32] Akabzaa, et al. (2007) The Glittering Façade: Effects of Mining Activities on Obuasi and Its Surrounding Communities. Third World Network-Africa, Accra, 78.

[33] Botchie, G., Fred, M.D. and Akabzaa, T. (2008) Open Cast Mining and Environmental Degradation Cost in Ghana. Technical Publication No. 87, Institute of Statistical, Social and Economic Research, University of Ghana, Accra.

[34] Boon, E. and Ababio, K. (2009) Corporate Social Responsibility in Ghana: Lessons from the Mining Sector. In: Proceedings of IAIA '09 Impact Assessment and Human Well-Being, International Association for Impact Assessment, Fargo.

[35] Yankson, P.W. (2010) Gold Mining and Corporate Social Responsibility in the Wassa West District, Ghana. Development in Practice, 20, 354-366. https://doi.org/10.1080/09614521003709965

[36] Nabdan District Assembly (NDA) (2014) District Profile. Ministry of Rural Government and Local Development, Accra.

[37] Talensi District Assembly (TDA) (2013) District Profile. Ministry of Rural Government and Local Development, Accra.

[38] Talensi District Assembly (TDA) (2014) District Profile. Ministry of Rural Government and Local Development, Accra.

[39] DFID (1999) Sustainable Livelihoods Guidance Sheets. DFID, London. 
[40] Hilson, G. (2010) Child Labour in African Artisanal Mining Communities: Experiences from Northern Ghana. Development and Change, 41, 445-473. https://doi.org/10.1111/j.1467-7660.2010.01646.x

[41] Hilson, G. (2002) Small-Scale Mining and Its Socio-Economic Impact in Developing Countries. Natural Resources Forum, 26, 3-13. https://doi.org/10.1111/1477-8947.00002

[42] Nabdan District Assembly (NDA) (2013) District Profile. Ministry of Rural Government and Local Development, Accra.

[43] Bloch, R. and Owusu, G. (2012) Linkages in Ghana's Gold Mining Industry: Challenging the Enclave Thesis. Resource Policy, 37, 434-442.

https://doi.org/10.1016/j.resourpol.2012.06.004 